\title{
The environmental implications of depleted uranium in Iraq and the principles of isolating it
}

\author{
N. Al-Ansari, S. Knutsson \& R. Pusch \\ Department of Civil, Environmental and Natural Resources Engineering, \\ Luleå University of Technology, Sweden
}

\begin{abstract}
Iraq experienced two devastating wars in 1991 and 2003, during which massive amounts of new weapons and sophisticated manufactured nuclear weapons called depleted uranium (DU) were used. DU is a by-product of the enrichment of natural uranium for nuclear reactor-grade or nuclear weapons-grade uranium. Depleted uranium is chemically identical to natural uranium. During the second Gulf war in 2003 U.S. and British troops used more than 1100 to 2200 tons of DU. As a consequence the ruminants of wars are reported to have seriously affected people and the environment, causing cancer and abnormal birth defects. The water and soil all over most of Iraq is contaminated. There is no strategy, national or international program for cleaning Iraq of DU wastes. Site selection criteria have been suggested for the disposal of radioactive waste but no principle of designing and constructing disposals. The present paper describes a large geological feature, a deep natural depression, which would be useful for isolating DU by isolating it in smectitic Iraqi clay.

Keywords: depleted uranium, Iraq, radioactive waste, military radioactive waste.
\end{abstract}

\section{Introduction}

Iraq occupies a total area of 437,072 square kilometers (fig. 1). The total population in Iraq is about $30,000,000$. The majority of the people occupy cities on the banks of the Tigris and Euphrates Rivers.

Iraq experienced two devastating wars in 1991 and 2003, during which massive amounts of new weapons and sophisticated manufactured nuclear weapons were used, called depleted uranium (DU). Depleted uranium (DU) is a 


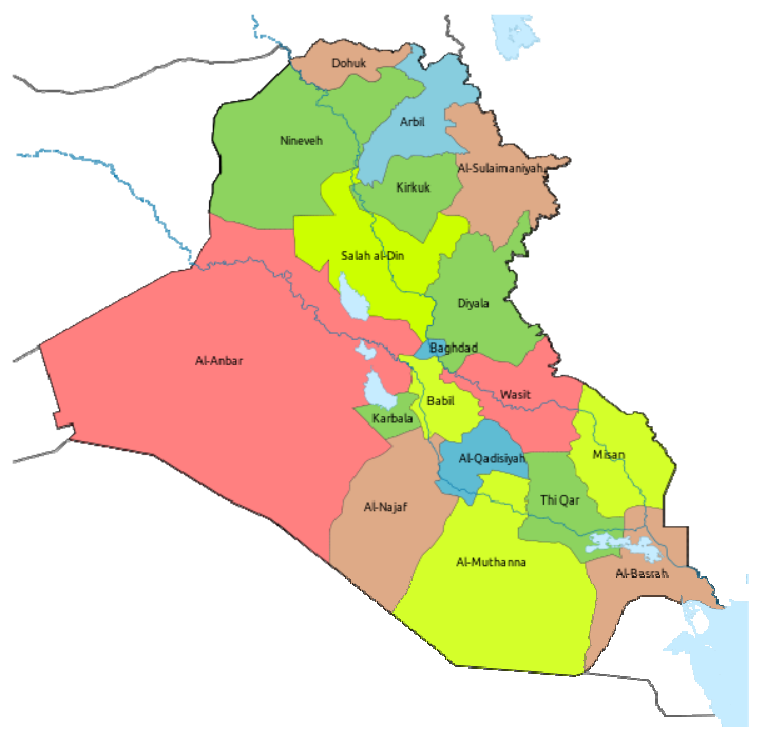

Figure 1: $\quad$ General map of Iraq.

by-product of the enrichment of natural uranium for nuclear reactor-grade or nuclear weapons-grade uranium. Depleted uranium is chemically identical to natural uranium. In DU most of the 235 isotope has been extracted leaving mainly the non-fissionable 238 isotope. It is used to make the tips of armor-piercing shells because it is extremely dense: 1.7 times as dense as lead. In addition, unlike other heavy metals that tend to flatten or mushroom upon impact, DU has the ability to "self-sharpen" as material spread out by the impact ignites and burns off as the munitions pierces its target [1-3].

In this research, the environmental implications of DU will be highlighted and solutions will be given to protect the environment in Iraq.

\section{Depleted uranium in Iraq}

DU was used twice by the Americans and allied forces against Iraqi troops and personnel in 1991 and 2003. During the second Gulf war in 2003 US and British troops have reportedly used more than five times as many DU bombs and shells as the total number used during the 1991 war for the invasion and occupation of Iraq . It was estimated that more than 1100 to 2200 tons of DU was used. This quantity is 400 to 800 more powerful than the ones used in the first Gulf war. According to Al-muqdadi [4] every 800 tons of DU is equivalent to 83 nuclear bombs. Hence the equivalent of about 250 nuclear bombs was dropped in the 2003 war.

Weyman [5] reported that the Uranium Medical Research Center published data about the quantities of DU used in Iraq can be summed up to consist of at least 2000 metric tons. 
The exact location that had been contaminated extends from southern to northern Iraq (fig. 2).

In addition to the radioactive contamination due to military activities in Gulf war II and III, other dangerous contamination was from the material and equipment at the Iraqi Energy Authority headquarters (fig. 2). Tons of uranium in the form of "yellow cake" as well as by-products from processing activities in addition to radioactive waste stored in barrels. In other parts of the Iraqi Energy Authority headquarter centre, there were about 200 barrels of isotopes and radioactive materials as well as yellow uranium oxides; they were all spilled on the ground. If a strong wind blows, it can carry these quantities to great distances outside. To this comes the problem with breeding in laboratories of insects used as biological insecticides. The expected ecological disaster from releasing thousands of flies known as chrysomya bezziana, nicknamed screw worm, from the headquarters became real when the flies were released by the looters. These flies were to be released after being sterilized [5].

Hall [6] stated that no place in Iraq is free from radioactive contamination, not even the "safe" Green Zone in Baghdad where military staff and civilian authorities, international journalists, and the Iraqi government live and work.
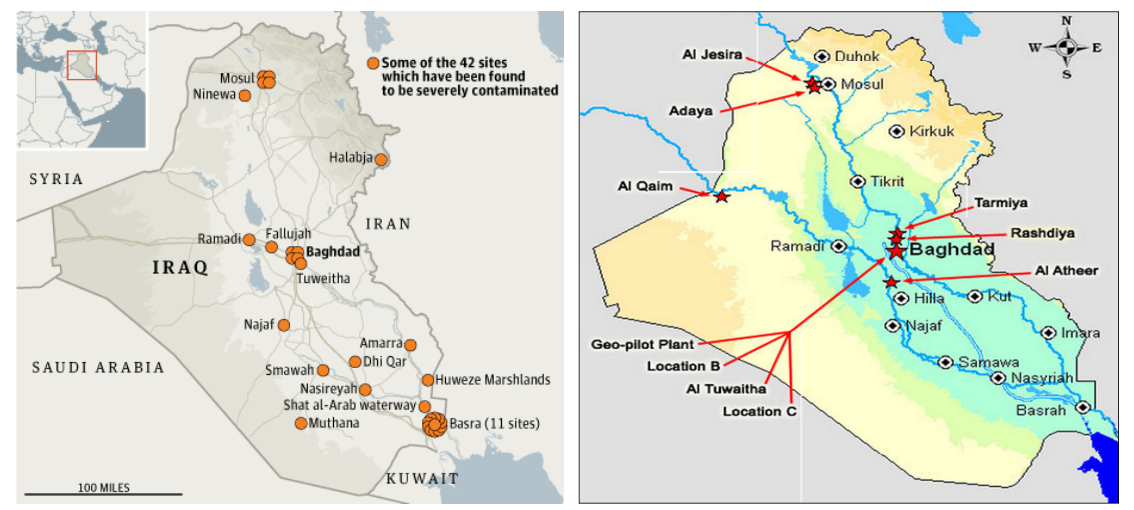

Figure 2: Contaminated sites with DU in Iraq. Left: Military action sites [23]. Right: Bombed nuclear facilities.

\section{Consequences of depleted uranium in Iraq}

Following the invasion of Iraq in 2003, over 140,000 cases of cancer have been reported, which are believed to be caused by toxic weaponry used by the occupying troops $[7,8]$.

Physical abnormality is increasing after the Gulf war where of 13,191 pregnancies among the partners of male Gulf vets, 686 , or 5.2 percent, had some form of physical abnormality, compared with 342 , or 3.5 percent, of the 9,758 non-Gulf pregnancies [9]. 


\section{Clean-up activities of contaminated areas in Iraq}

Major areas of engagement in Operation Iraqi Freedom cover more than 300 sites all over Iraq. The soil as well as the military equipment in all these sites are believed to be contaminated by DU used by American and allied forces. Due to the abnormal high radiation rates in these sites and their effect on humans and environment, the Iraqi Government and the American and allied forces (coalition forces) carried out clean up and soil replacement activities.

A comprehensive survey has been made on the sites where coalition forces tried to clean [5]. The aim of this operation was to remove potentially contaminating soil from living and working areas and this activity showed that fine, contaminated dust is spreading over areas where there are at least 5,000,000 residents in Baghdad alone.

\section{Ways of isolating solid waste}

\subsection{Principles and location}

The two common principles of disposing hazardous waste are to construct landfills that are isolated by clay-based liners covering the waste mass and underlying it for separation from the groundwater, or to place the waste underground and isolate it from the surrounding rock or soil by clay or concrete. Both techniques are proposed for disposal of contaminated soil, DU weapon and ammunition and other military scrap. The most strongly contaminated waste, classified as low-level waste with a required time of isolation of 300 years, can preferably be placed in clay-isolated concrete vaults according to the Lithuanian, French and Spanish concepts. However, the climatic conditions in Iraq offer simpler and cheaper versions of the landfill concept than in Europe for disposing such waste. Thus, high temperature and very low precipitation make it possible to use thin top liners and to omit the bottom liner. Necessary overburden for providing sufficient effective pressure on the top liner and retarding hydration of it is easily prepared of desert sand. The fact the groundwater level is more than $100 \mathrm{~m}$ below the ground surface in the deserts of western and southern Iraq eliminates the risk of wetting of the waste from below.

A special case that we will describe in this document is the particularly good conditions for disposal of large amounts of solid waste like weapons, ammunition and vehicles in a deep depression in the western part of Iraq.

\subsection{Site selection}

Selection of a suitable site for locating a landfill a DU and military scrap requires that one considers its effect on humans, the environment, water resources, air, and soil as well as other utilities like transportation and power supply. In addition, the landfill should have sufficient capacity to meet the current and projected waste to be deposited within at least 10 years. A number of criteria have been proposed for landfill sitting [10-12], the most important ones concerning: 
- Distance from towns, airports, highways and public parks and recreation areas,

- Depth to groundwater level,

- Permeability of the underground (soil or rock),

- Risk of flooding,

- Nearness to surface water,

- Discharge of water from the landfill, a matter of topography, - distance to protected areas or areas used for breeding animals,

- Nearness to fault areas and karst terrain with sinkholes,

- Seismicity especially for sites with nearby reservoirs,

- Rainfall duration and intensity, temperature, humidity and wind speed and direction.

The priorities of the above conditions will vary from one site to another. Specific criteria are usually recommended values and the combined function of two or more conditions must be considered.

\subsection{Space-requiring DU waste}

Most of the battered remnants of the Iraqi wars are radioactively contaminated. Despite the passage of two decades of the first war and 8 years of the second war these remains are still radioactive and residues are found in farm fields, along roads, near residential areas (fig. 3).

It is believed that there are three places in Iraq that can satisfy the above site selection criteria all of them being in desert terrain, which represents $60 \%$ of the total land area of Iraq. They are termed the Western deserts, Southern deserts and Al-Jazira deserts of which the latter is in northern Iraq (fig. 4), [13-15]. The proposed design of landfills in these areas is reported [16-20] worked out with special respect to the stability of the slopes of the top liners and overfill and to the present exogenic conditions including climate and seismicity.
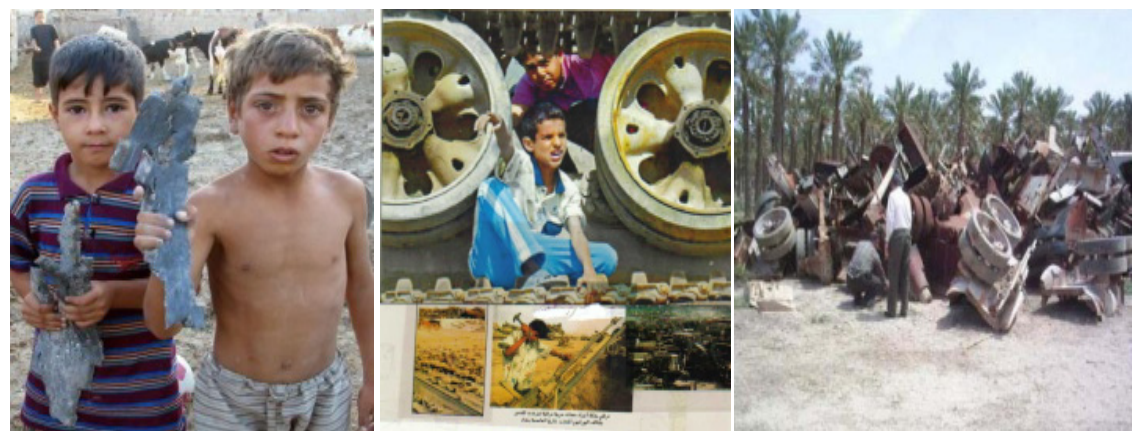

Figure 3: $\quad$ Military scrap yards in Iraq. 


\subsection{The special case of Umm Chaimin depression}

\subsubsection{Geological conditions}

A potential candidate site for disposal of large quantities of radioactive waste represented by DU, ammunition, weapons and wrecked vehicles is the Umm Chaimin depression (figs. 4, 5). It is a topographic depression, almost circular in shape, with a long diameter of about $2.9 \mathrm{~km}(\mathrm{~N}-\mathrm{S}$ direction) and a short diameter of $2.5 \mathrm{~km}$. (E-W direction). It is $28 \mathrm{~m}$ to $38 \mathrm{~m}$ deep and located $95 \mathrm{~km}$ southwest of Rutbah city in the Western desert, the surrounding area being flat. The area of the top of the depression at closed contour line is $5.73 \mathrm{~km}^{2}$ and its total volume $0.10953 \mathrm{~km}^{3}$ [21]. The floor of the depression is composed of Quaternary sediments to a depth of $72 \mathrm{~m}$ overlying limestones and claystones of Paleocene or Late Cretaceous age. The Quaternary sediments are compact fine illite clay over $30 \mathrm{~m}$ of breccia.

On the rim of the depression the rock consists of $10 \mathrm{~m}$ of silicified limestone interbedded with dolomitic limestones, followed by $20 \mathrm{~m}$ of very coarse crystalline limestones. The sloping boundaries have a dip of $4-60^{\circ}$ [21]. The depression is most probably of karst origin developed within the limestones of the Ratga Formation (Eocene) and possibly in gypsum and anhydrite beds, causing collapse of the roof. The age of the depression is estimated to be Early-Late Pleistocene [21]. It is being proposed as a DU disposal site and would well be considered as a major candidate although it has been recommended to implement a comprehensive program for further assessing its suitability as well as that of the aforementioned landfills [22].

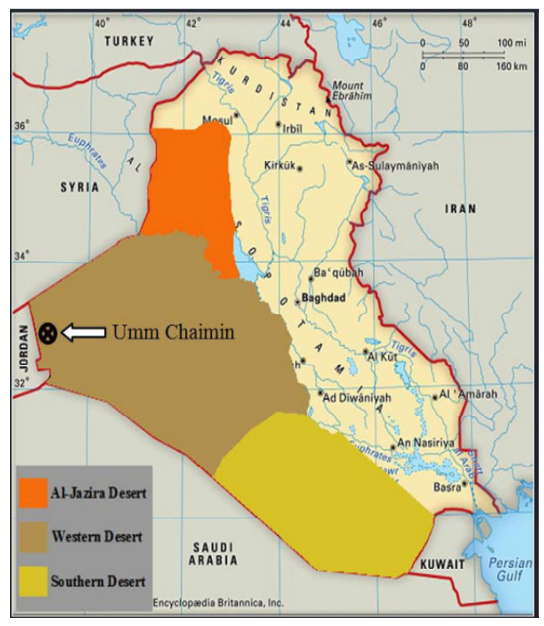

A

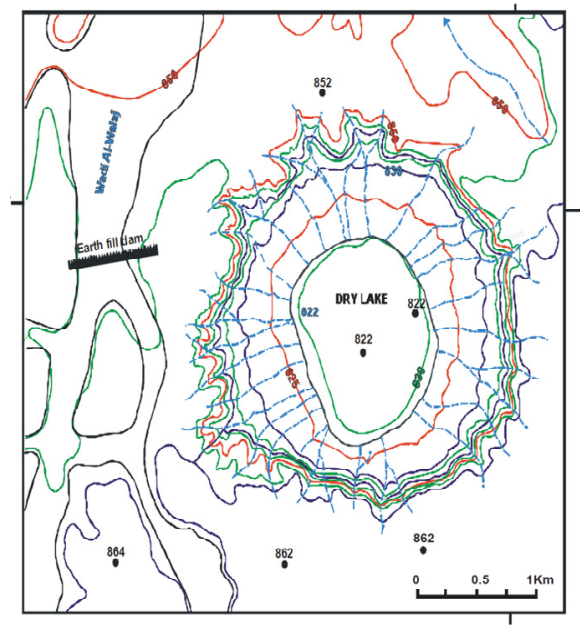

B

Figure 4: A: Western, Southern and Jezera Deserts in Iraq. B: Topographic map of Umm Chaimin. 

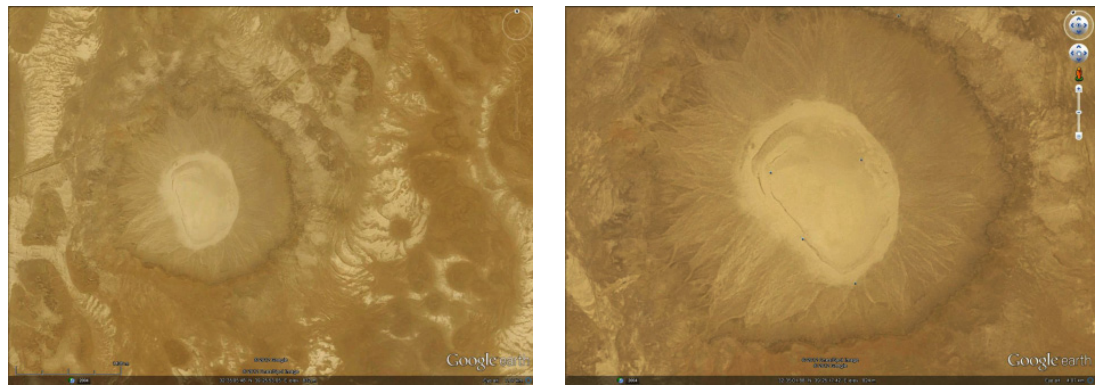

Figure 5: $\quad$ Satellite images of Umm Chaimin.

\subsubsection{Hydrological conditions}

Being located in desert terrain and containing no free water the Umm Chaimin depression is not hydrologically active and has probably been dried out since Tertiary time. Under prevailing climatic conditions it will remain dry for very long periods of time and most certainly for the required 300 years of isolation of DU-type waste from flowing groundwater. However, rain occasionally falls and placed waste materials must be shielded during placement and arranging the site to become a complete repository.

\subsubsection{Proposed design principle}

The final state of the Umm Chaimin deposition site would preferably involve complete filling of the whole depression with waste up to 5-10 m below the ground level of the surrounding terrain and with the waste being covered by lowpervious clayey material up to this level. The top of this layer should have a conical shape and be covered by a conformable coherent slab of on-site cast cement-poor concrete. The concrete is in turn covered by a "top liner" of a few decimetres of expandable clay mixed with sand over which a filter of silt/sand is placed. The uppermost part of the whole series of barriers is a several meter thick erosion-protective layer of coarse gravel and blocks. The top of the whole depression would thus form a hill with a height of some tens of meters over the surrounding terrain in its central part so that rain is drained off through the uppermost erosion-resisting layer to the surrounding desert sand. The movement of infiltrated rain water in the clayey top liner below the erosion protection will be of cyclic type with evaporation in dry periods and temporary hydration in wet periods. For preserving the microstructural constitution during such cycles the granulometry shall be selected so that no expansion or shrinkage can take place.

For maximizing the isolating function, expandable clay is preferably placed on the slopes of the depression and between layers of waste material in the course of the waste filling operation. This will delay hydration of the waste by many tens of thousands of years even if the groundwater level is raised up to the present ground level. Care has to be taken to shield filling materials and waste from rain in the repository construction phase, which can be very long. 


\section{Conclusions}

During the first Gulf war in 1999, 300 tons of depleted uranium was used. In 2003 Gulf war it is believed that another 1000 to 2000 tons of DU accumulated. Remnants of DU weapons used in 1991 and 2003 wars constitute a major threat to the environment and including humans, animals and plants.

The cheapest technique to get rid of the contaminated radioactive military scrap waste is to bury it. The climatic, hydrological and geological conditions make the deserts in the western, northern and southern parts of the country suitable for the deposition of DU-contaminated soil and wrecked armor. It is proposed, that the waste should be brought from the fifteen sites that are most heavily contaminated by DU to a small number of disposal sites in the western, northern and southern deserts areas. These disposal sites can be of different size depending on the amount and type of waste. Umm Chaimin depression in the western desert seems to be a very good suitable candidate site for burying radioactive military waste.

Public awareness program should be launched about the potential risks and to introduce protection measures, including warning signs and restricting access to contaminated locations and storage sites. A well planned system for transport and disposal of DU and other war-related radioactive waste is a must for Iraq.

\section{References}

[1] Bollyn, C., The Real Dirty Bombs: Depleted Uranium, Nuclear Age Peace Foundation, 2004.

[2] Wagner, F. \& Thurn, V., The Doctor, the Depleted Uranium and the Dying Children, documentary film produced for German television and released by Ochoa-Wagner Produktion in 2004 in Germany, exposes the use and impact of radioactive weapons during the current war against Iraq, 2005.

[3] Rowe, D.G., Depleted Uranium casts a shadow over peace in Iraq, The New Scientist Magazine, issue 2391, $19^{\text {th }}$ April 2003.

[4] Al-muqdadi, K., When are Iraqi contaminated sites really cleaned?, J. Life and Environment, V 19 (in Arabic), 2007.

[5] Weyman, Tedd, Abu Khasib to Al Ah'qaf: Iraq Gulf War II, Field Investigations report, Uranium Medical Research Centre, http://www.umrc.net/os/downloads/Iraq_report_1.doc 2003

[6] Hall, I.W., Depleted Uranium for Dummies, 2006. http://www.notinkansas.us/du_3.html

[7] Press TV, Radioactive US weapons taking toll in Iraq, 2010. http://www.presstv.ir/detail.aspx?id=104356\&sectionid=351020201

[8] Ross, S., "We are living through another Hiroshima Iraqi" doctor says, uruknet.info, informazione dal medio oriente information from Middle East, 2008. http://www.uruknet.de/?p=m42361\&hd=\&size $=1 \& 1=\mathrm{e}$

[9] LaForge, J., Nuke watch Pathfinder, 2004.http://www.nukewatch.com /quarterly/20042summer/20042page2.pdf

http://www.grassrootspeace.org/depleted_uranium_iraq.html 
[10] Tchobanoglous, G., Theisen, H., \& Vigil, S.A., Integrated solid waste management. Mc Graw-Hill, Inc., N Y, 1993.

[11] BCRC, Preparation of a set of tools for the selection, design and operation of hazardous waste landfills in hyper-dry areas, Regional Center for Training and Technology Transfer for the Arab States, 55, 2005.

[12] EPA, US-Environmental Protection Agency of United State, Municipal Solid Waste Landfill Criteria. Found at: http://www.epa.gov/epaoswer/ non-hw/muncpl/landfill techman

[13] Al-Ansari, N.A., Locating landfills in Arid Environment, J. Earth Sciences and Geotechnical Eng., 3, 3, pp. 11-24, 2013.

[14] Al-Ansari, N., Pusch, R. \& Knutsson, S., Suggested landfill sites for hazardous waste in Iraq, J. Natural Science, 5, 4, pp. 463-477, 2013.

[15] Al-Ansari, N., Pusch, R., Knutsson, S., \& Almuqdadi, K., Isolation of Radioactive Military Wastes in Iraq, J. Earth Sciences and Geotechnical Eng., 3, 3, pp. 1-10, 2013.

[16] Pusch, R., On the risk of liquefaction of buffer and backfill. SKB Technical Report TR-00-18, 2000.

[17] Pusch, R. and Khil, A., Percolation of clay liners of ash landfills in short and long time perspectives. Waste Management Research, 22, 2, pp. 71-77, 2004.

[18] Pusch, R. and Weston, R., Superior techniques for disposal of highly radioactive waste (HLW). Progress in Nuclear Energy, 59, pp. 75-85. doi: 10.1016/j.pnucene.2012.

[19] Pusch, R. \& Yong, R. N., Microstructure of smectite clays and engineering performance [electronic resource], London, New York: Taylor \& Francis, 2006.

[20] Pusch, R., Kasbohm, J., Pacovskt, J. \& Cechova, Z., Chemical stability of montmorillonite buffer clay under repository-like conditions-A synthesis of relevant experimental data. Applied Clay Science, 47(1-2), pp. 113-119, 2010.

[21] Sissakian, V.K. \& Jabbar, M.F.A., Using Remote Sensing and GIS Techniques in Detecting the Origin of Umm Chaimin Depression, West Iraq, Iraqi Bul. Geol. and Mining, 4, 2, 51-72, 2008.

[22] Zwijnenburg, W., In the state of Uncertainty: Impact and implications of the use of depleted uranium in Iraq, IKV PAX CHRISTI report, p. 52. www.ikvpaxchristi.nl, 2013.

[23] Chulov, M., Iraq littered with high levels of nuclear and dioxin contamination, study finds, guardian.co.uk, 22 January 2010. 